\title{
Pengaruh Pengungkapan Enterprise Risk Management dan Pengungkapan Intellectual Capital Terhadap Nilai Perusahaan dengan Good Corporate Governance Sebagai Moderasi
}

\author{
Astina Elisabeth S. Emar* dan Sri Ayem \\ Universitas Sarjanawiyata Tamansiswa Yogyakarta \\ *astinaemar@gmail.com
}

How to cite (in APA style):

Emar, S, E,A., Ayem, S. (2020). Pengaruh Pengungkapan Enterprise Risk Management dan Pengungkapan Intellectual Capital Terhadap Nilai Perusahaan dengan Good Corporate Governance Sebagai Moderasi. 19(2), pp.78-90. https://doi.org/10.22225/we.19.2.1956.79-90

\begin{abstract}
The purpose of this study was to know the impact of enterprise risk management (ERM) disclosure and intellectual capital (IC) disclosure to the company's value with good corporate governance (GCG) as the moderate variable. The sample in this study were manufacturing companies listed on the Indonesian Stock Exchange (IDX) in 2016-2018 with total of 66 companies based on purposive sampling method. The analysis technique used is linear regression and moderated regression analysis (MRA). The study results indicated that ERM disclosure does not affect the company's value and IC disclosure has a significance positive effect on company's value, while GCG variables are unable to moderate the effect of ERM disclosure on company's value and GCG can strengthen the effect of IC disclosure to the company's value.
\end{abstract}

Keywords: Enterprise risk management disclosure; intellectual capital disclosure; good corporate governance; company,s value.

\begin{abstract}
Abstrak
Tujuan dari penelitian ini adalah untuk mengetahui pengaruh pengungkapan enterprise risk management (ERM) dan pengungkapan intellectual capital (IC) terhadap nilai perusahaan dengan good corporate governance (GCG) sebagai variabel moderasi. Sampel dalam penelitian ini adalah perusahaan manufaktur yang terdaftar di Bursa Efek Indonesia (BEI) tahun 2016-2018 sebanyak 66 perusahaan yang diperoleh dengan metode purposive sampling. Teknik analisis yang digunakan adalah analisis regresi linear dengan moderasi. Hasil penelitian menunjukkan bahwa pengungkapan ERM tidak berpengaruh terhadap nilai perusahaan dan pengungkapan IC berpengaruh positif pada nilai perusahaan, sedangkan variabel moderasi GCG tidak mampu memoderasi pengaruh pengungkapan ERM pada nilai perusahaan dan GCG dapat memperkuat pengaruh pengungkapan IC terhadap nilai perusahaan.
\end{abstract}

Kata kunci: Pengungkapan enterprise risk management; pengungkapan intellectual capital; good cororate governance; nilai perusahaan.

\section{PENDAHULUAN}

Dalam dunia bisnis yang semakin bersaing, sebuah perusahaan semakin dituntut untuk harus mampu meningkatkan kemakmuran pemegang saham dengan cara memaksimalkan nilai perusahaan. Nilai perusahaan adalah nilai pasar yang mampu memberikan kemakmuran bagi pemegang saham secara maksimum jika harga saham perusahaan terus meningkat (Rivandi, 2018). Nilai perusahaan yang tinggi dapat meningkatkan kemakmuran para pemegang saham (Hapsari, 2018). Menurut teori sinyal, informasi yang dikeluarkan oleh perusahaan sangat penting dalam menentukan keputusan investasi bagi pihak di luar perusahaan. Menurut Rivandi (2018), teori sinyal menekankan pada pentingnya informasi yang dikeluarkan oleh perusahaan, karena informasi merupakan unsur penting bagi investor dalam melakukan investasi dan dasar pengambil keputusan.

Beberapa faktor yang dapat mempengaruhi nilai perusahaan diantaranya adalah pengungkapan enterprise risk management, intellectual capital dan juga tata kelola perusahaan yang baik. Suatu perusahaan dinilai lebih baik jika mampu melakukan pengungkapan secara lebih luas karena akan dinilai lebih baik jika mampu menerapkan prinsip keterbukaan informasi atau transparansi (Devi, Budiasih, \& Badera, 2017). Dalam mengelola risiko penting bagi perusahaan untuk menerapkan 
enterprise risk management (ERM) terlebih dahulu. Aditya \& Naomi (2017) menjelaskan bahwa ERM dirancang untuk mengidentifikasi kejadian potensial yang dapat mempengaruhi perusahaan, dan mengelola risiko agar berada pada tingkat risiko dapat dikontrol oleh perusahaan. Hery (2015) menjelaskan bahwa ERM merupakan suatu proses yang sistematis dan berkelanjutan yang dirancang dan dijalankan oleh manajemen guna memberikan keyakinan yang memadai bahwa semua risiko yang berpotensi memberikan dampak negatif telah dikelola sedemikian rupa sesuai dengan tingkat risiko yang bersedia diambil perusahaan. Salah satu fenomena risiko bisnis yang muncul pada Mei 2015 pada perusahaan Toshiba Corporation Jepang yang melakukan suatu kebohongan melalui accounting fraud senilai 1,2 milyar dolar Amerika dan akhirnya harus menghadapi tuntutan pembayaran dari para pemegang sahamnya sebesar 174 miliar yen. Kasus fraud juga terjadi pada lembaga pembiayaan SNP Finance (Liputan6.com) pada tahun 2017 yang diketahui melakukan rekayasa laporan keuangan, sehingga merugikan 14 bank di Indonesia. Fenomena fraud tersebut adalah contoh risiko internal perusahaan yang dapat terjadi akibat lemahnya manajemen risiko perusahaan (enterprise risk management). Implementasi enterprise risk management dalam perusahaan dapat membantu mengontrol aktivitas manajemen sehingga perusahaan dapat meminimalisasi terjadinya fraud yangdapat merugikan perusahaan (Devi dkk., 2017).

Pengungkapan ERM merupakan informasi pengelolaan risiko yang dilakukan oleh perusahaan dan mengungkapkan dampaknya terhadap masa depan perusahaan. ERM mulai diperkenalkan oleh Committee of Sponsoring Organizations (COSO) sejak tahun 2004 dalam Devi dkk. (2017) yang terdiri dari 8 dimensi yaitu Lingkungan Internal, penetapan tujuan, identifikasi kejadian, penilaian risiko, respon terhadap risiko (risk response), aktivitas pengendalian, informasi dan komunikasi serta monitoring.

Selain pengungkapan enterprise risk management, pengungkapan intellectual capital juga penting dalam meningkatkan nilai perusahaan. Intellectual Capital mulai berkembang di Indonesia setelah munculnya PSAK 19 (Revisi 2009) dalam Suparsa, dkk., (2017) tentang aktiva tidak berwujud. Pengungkapan Intellectual Capital (IC) merupakan bagian dari aset tidak berwujud yang terdiri dari tiga komponen utama organisasi, yaitu modal manusia (human capital), modal organisasi (structural capital atau organizational capital), dan modal pelanggan (relational capital atau customer capital) (Mariani \& Suryani, 2018). Ketiga komponen tersebut merupakan aspek-aspek penting yang diperlukan oleh perusahaan untuk memaksimalkan kinerja perusahaan. Kemampuan bersaing juga terletak pada pengetahuan sumber daya manusia, inovasi, dan sistem informasi yang dimiliki. Dalam teori Stakeholder para stakeholder dan perusahaan saling mempengaruhi.

Dalam sebuah perusahaan dibutuhkan juga suatu tata kelola perusahaan atau yang biasa disebut Good Corporate Governance (GCG) untuk mengendalikan dan menjalankan perusahaan. Menurut Sulistyaningsih \& Gunawan (2018), peningkatan corporate governance merupakan salah satu cara yang dapat digunakan untuk mengurangi risiko perusahaan. Menurut Puspitasari \& Ermayanti (2019), GCG diterapkan guna memenuhi kepercayaan masyarakat yang mana dijadikan dasar perusahaan untuk berkembang.

Hasil penelitian Devi dkk. (2017), Handayani (2017) dan Pratiwi (2019) menemukan bahwa pengungkapan enterprise risk management berpengaruh positif terhadap nilai perusahaan. Bertentangan dengan hasil penelitian Arianto dan Rivandi (2018), Putuyana \& Budiarto (2018) serta penelitian Aditya \& Naomi (2017), yang menemukan bahwa pengungkapan ERM tidak berpengaruh terhadap nilai perusahaan, sedangkan penelitian terkait pengungkapan intellectual capital yang dilakukan oleh Devi dkk. (2017), Rivandi (2018) menemukan bahwa pengungkapan IC berpengaruh positif terhadap nilai perusahaan, bertentangan dengan hasil penelitian Putuyana \& Budiarto (2018), Mariani \& Suryani (2018) dan Pratiwi (2019), yang menemukan pengungkapan IC tidak berpengaruh terhadap nilai perusahaan. Perbedaaan hasil penelitian tersebut mendorong penelitian ini dilakukan untuk menguji kembali pengaruh pengungkapan ERM pada perusahaan-perusahaan manufaktur yang ada di Indonesia. Pengembangan konsep penelitian yang membedakan penelitian ini dengan penelitian sebelumnya adalah penelitian ini menggabungkan antara pengungkapan ERM dan pengungkapan IC sebagai variabel independen dan juga good corporate governance yang diproksikan dengan dewan komisaris independen sebagai variabel moderasi. Pemilihan dewan komisaris independen sebagai variabel moderasi karena tidak mempunyai afiliasi dengan perusahaan dan dengan keberadaan dewan komisaris independen diyakini dapat mempengaruhi kualitas laporan keuangan dalam hal meningkatkan transparansi pengungkapan. Farhani \& Andraeny (2018), menjelaskan bahwa komisaris independen mempunyai tugas untuk melakukan pengawasan terhadap 
penyajian laporan keuangan perusahaan. Dewan independen tidak memiliki saham di perusahaan, ini berarti mereka dapat mengambil keputusan yang tidak bias dan meluruskan kepentingan agen dengan kepentingan pemegang saham (Khan dkk., 2018).

\section{TINJAUAN PUSTAKA}

\section{Teori Sinyal (Signalling Theory)}

Teori sinyal lebih menekankan kepada pentingnya informasi yang dikeluarkan oleh perusahaan terhadap keputusan investasi pihak di luar perusahaan. Informasi merupakan unsur penting bagi investor dan pelaku bisnis karena informasi pada hakekatnya menyajikan keterangan, catatan atau gambaran baik untuk keadaan masa lalu, saat ini maupun keadaan masa yang akan datang bagi kelangsungan hidup suatu perusahaan dan bagaimana pasaran efeknya. Pengungkapan yang lebih luas memberikan informasi bahwa perusahaan tersebut telah lebih baik dibandingkan perusahaan lain karena telah menerapkan prinsip transparansi (Pratiwi, 2019).

\section{Teori agensi (Agency Theory)}

Teori keagenan (Agency Theory) mendasarkan hubungan kontrak antara pemegang saham atau pemilik (principal) dan manajemen atau manajer (agent). Dalam teori keagenan, pemisahan peran terjadi antara agent dan principal yang berpotensi menimbulkan konflik keagenan. Konflik tersebut dapat mengakibatkan nilai perusahaan rendah sehingga tingkat kepercayaan principal semakin menurun terhadap manajemen perusahaan. Konflik keagenan tersebut dapat diminimalisir oleh suatu mekanisme pengawasan. Mekanisme pengawasan digunakan yaitu mekanisme struktur pengelolaan. Mekanisme struktur pengelolaan sebagai suatu sistem yang mengatur dan mengendalikan perusahaan yang diharapkan agar memberikan pengawasan terhadap agent dalam mengelola perusahaan sehingga dapat meyakinkan principal bahwa agent bekerja sesuai kepentingan principal. Prespektif teori agensi dapat digunakan dalam memahami prinsip tata kelola perusahaan atau corporate governance (Tambunan, Saifi, \& Hidayat, 2017).

\section{Pengaruh pengungkapan Enterprise risk management terhadap nilai perusahaan}

Teori Sinyal menjelaskan bahwa informasi merupakan unsur penting bagi investor dan pelaku bisnis karna menyajikan keterangan, gambaran dan keadaan suatu perusahaan. Informasi yang lengkap dan relevan diperlukan untuk pengambilan keputusan. Salah satunya adalah informasi tentang profil risiko perusahaan dan pengelolaan atas risiko tersebut yang biasa disebut pengungkapan Enterprise Risk Management (ERM).

Pengungkapan ERM merupakan pengungkapan atas risiko yang telah dikelola perusahaan atau pengungkapan atas upaya dalam mengendalikan risiko (Astuti, 2018). Luas pengungkapan manajemen risiko menunjukkan kemampuan sebuah perusahaan dalam mengelola manajemen risikonya (Cecasmi \& Samin, 2019). Enterprise riskmanagement dalam suatu perusahaan memiliki peran penting untuk menjaga stabilitas perusahaan (Ardianto \& Rivandi, 2018). Hasil penelitian Devi dkk. (2017) dan penelitian Handayani (2017) membuktikan bahwa pengungkapan ERM berpengaruh positif dan signifikan terhadap nilai perusahaan. Pengungkapan ERM dalam suatu perusahaan menggambarkan adanya tata kelola risiko perusahaan yang baik. Pengungkapan ERM yang berkualitas tinggi pada suatu perusahaan memberikan dampak positif pada presepsi pelaku pasar yang dapat berpengaruh pada peningkatan nilai perusahaan tersebut (Devi dkk., 2017). Berdasarkan uraian tersebut maka disimpulkan bahwa semakin tinggi atau luas pengungkapan enterprise risk management yang dilakukan maka semakin tinggi juga nilai perusahaannya, maka hipotesis pertama adalah sebagai berikut:

H1: pengungkapan enterprise risk management berpengaruh positif terhadap nilai perusahaan.

\section{Pengaruh pengungkapan intellectual capital terhadap nilai perusahaan}

Intellectual capital (modal intelektual) adalah asset tidak berwujud berupa sumber daya informasi serta pengetahuan yang berfungsi untuk meningkatkan kemampuan bersaing serta dapat meningkatkan kinerja perusahaan dan menciptakan nilai perusahaan. Informasi tentang intellectual capital memiliki peran yang sangat penting karena menggambarkan informasi non finansial perusahaan (Putuyana \& Budiarto, 2018). 
Menurut teori sinyal pentingnya informasi yang dikeluarkan oleh perusahaan dapat mempengaruhi terhadap keputusan investasi pihak di luar perusahaan. Pengungkapan intellectual capital merupakan salah satu informasi penting yang diperlukan oleh investor. Rivandi, (2018) menemukan hasil pengungkapan intellectual capital berpengaruh positif terhadap nilai perusahaan. Semakin tinggi jumlah intellectual capital disclosure maka semakin tinggi nilai perusahaan karena investor dapat menangkap sinyal yang diberikan oleh perusahaan. Penelitian yang dilakukan Devi dkk. (2017) juga menemukan bahwa pengungkapan intellectual capital berpengaruh positif terhadap nilai perusahaan. Menurut Pamungkas \& Maryati (2017), pengungkapan intellectual capital dibutuhkan oleh investor karena mencerminkan kapabilitas perusahaan di masa mendatang. Berdasarkan uraian tersebut maka diajukan hipotesis kedua sebagai berikut:

H2: pengungkapan intellectual capital berpengaruh positif terhadap nilai perusahaan.

\section{Good corporate governance dalam memperkuat pengaruh pengungkapan enterprise risk management terhadap nilai perusahaan}

Penerapan pengungkapan ERM berkaitan dengan penerapan good corporate governance (GCG), khususnya pada salah satu prinsip GCG yaitu transparansi yang mewajibkan adanya aktifitas pemantauan dan manajemen resiko dalam perusahaan yang dilakukan secara menyeluruh (Agista \& Mimba, 2017).

Teori agensi menjelaskan bahwa pemisahaan peran terjadi antara agen (manajer) dan principal (pemegang saham) sehingga dapat menimbulkan konflik keagenan. Dimana terdapat perbedaan kepentingan yang dapat mendorong agen melakukan hal-hal yang tidak sesuai kepentingan pemegang saham atau principal. Salah satunya adalah terjadinya asimetri informasi atau ketidakseimbangan informasi dimana agen berada pada posisi yang memiliki informasi yang lebih banyak tentang perusahaan sehingga dapat mendorong agen untuk menyembunyikan beberapa informasi yang tidak diketahui principal. Muslih \& Mulyaningtyas (2019), menjelaskan bahwa untuk mengurangi adanya risiko maka diperlukan suatu sistem yang dapat mengarahkan dan mengendalikan suatu perusahaan seperti corporate governance. Dengan penerapan GCG yang baik dapat mengurangi konflik keagenan dan diharapkan dapat menciptakan nilai perusahaan secara berkesinambungan melalui pola pertumbuhan yang sehat dalam jangka panjang. Peningkatan corporate governance merupakan salah satu cara yang dapat digunakan untuk mengurangi risiko perusahaan Sulistyaningsih \& Gunawan (2018). Semakin kecil potensi risiko bisnis, maka semakin aman bagi perusahaan dalam menjalankan usahanya (Suryanata dkk., 2019). GCG bertujuan untuk menaikkan nilai perusahaan dalam jangka panjang dengan tetap memperhatikan kepentingan para pemegang saham. Perusahaan yang melaksanakan GCG dapat menghadapi ancaman dan risiko dari internal maupun eksternal perusahaan. Melalui pengawasan dan pengendalian yang dilakukan oleh GCG diyakini dapat meningkatkan transparansi dalam pengungkapan manajemen risiko yang dilakukan. Pengungkapan enterprise risk management menunjukkan bahwa good corporate governance telah diterapkan dengan baik. Berdasarkan uraian tersebut dapat diajukan hipotesis ketiga yaitu:

H3: good corporate governance memperkuat pengaruh pengungkapan ERM terhadap nilai perusahaan.

\section{Good corporate governance dalam memperkuat pengaruh pengungkapan intellectual capital terhadap nilai perusahaan}

Menurut teori keagenen konflik keagenan dapat terjadi antara principal dan manajemen yang membuat kepercayaan principal menurun terhadap manajemen sehingga berdampak pada nilai perusahaan. Oleh karena itu dibutuhkan sebuah mekanisme pengawasan yakni struktur pengelolaan atau good corporate governance yang mengatur dan mengendalikan perusahaan agar dapat meyakinkan principal bahwa agen bekerja sesuai kepentingan principal.

Salah satu prinsip dari GCG adalah transparency atau keterbukaan dalam pengungkapan informasi materiil dan relevan mengenai suatu perusahaan atau organisasi. Dengan penerapan GCG diharapkan dapat mendorong perusahaan melakukan pengungkapan informasi intellectual capital perusahaan.

Menurut Suparsa dkk. (2017), penerapan tata kelola perusahaan atau GCG yang baik dapat memberi sinyal positif kepada para investor sehingga meninkatkan nilai perusahaan. Pengungkapan intellectual capital dapat meningkatkan kinerja perusahaan sehingga nilai perusahaan dapat 
ditingkatkan. Semakin luas pengungkapan IC yang dilakukan maka semakin tinggi nilai perusahaan. Verawaty dkk. (2017), meneliti tentang pengaruh intellectual capital terhadap nilai perusahaan dengan GCG sebagai variabel moderasi, hasil penelitian menunjukkan bahwa variabel GCG dapat memoderasi pengaruh intelllectual capital terhadap nilai perusahaan. Hal ini menunjukkan bahwa GCG mampu menciptakan nilai perusahaannya dengan cara pengungkapan intellectual capital. Berdasarkan uraian tersebut dapat dirumuskan hipotesis keempat yaitu:

H4: good corporate governance dapat memperkuat pengaruh pengungkapan IC terhadap nilai perusahaan.

\section{METODE}

Data yang digunakan dalam penelitian ini adalah data sekunder dari laporan keuangan perusahaan manufaktur yang terdaftar di BEI tahun 2016-2018. Metode pemilihan sampel pada penelitian ini menggunakan metode purposive sampling dengan kriteria sebagai berikut: (1) Perusahaan manufaktur yang terdaftar di BEI 2016-2018, (2) Perusahaan yang mempublikasikan laporan keuangan berturut-turut selama tahun 2016-2018, (3) Menyajikan laporan dalam bentuk mata uang Rupiah, (4) Memiliki data lengkap terkait variabel-variabel yang digunakan dalam penelitian. Berdasarkan kriteria tersebut diperoleh sampel sebanyak 198 sampel dari 66 perusahaan.

\section{Definisi operasional variabel}

\section{Pengungkapan Enterprise Risk Management}

Enterprise Risk Management merupakan pengungkapan atas risiko yang telah dikelola atau pengungkapan atas upaya perusahaan dalam menendalikan risiko. Berdasarkan ERM Framework yang dikeluarkan oleh COSO, terdapat 108 item pengungkapan ERM yang mencakup delapan dimensi yang digunakan dalam Pratiwi (2019). Skala dikotomi tertimbang (unweughteddichotomousscale) digunakan dalam pemberian skor untuk setiap item pengungkapan diberi nilai 1, dan 0 apabila tidak diungkapkan (Devi dkk., 2017).

$$
\text { ERMDI }=\frac{\sum_{\mathrm{ij}} \mathrm{D}_{\mathrm{item}}}{\sum_{\mathrm{ij}} \mathrm{AD}_{\mathrm{item}}}
$$
Keterangan:
ERMDI :
ERM Disclosure index
$\boldsymbol{\Sigma}_{\mathrm{ij}} \mathrm{D}_{\mathrm{item}} \quad$ :
Total skor item ERM yang diungkapkan
$\boldsymbol{\Sigma}_{\mathrm{ij}} \mathrm{AD}_{\mathrm{item}}$
Total skor item ERM yang seharusnya diungkapkan

\section{Pengungkapan Intellectual Capital}

Intellectual Capital merupakan jumlah pengungkapan informasi tentang intellectual Capital yang disajikan dalam laporan tahunan. Intellectual Capital Disclosure diproksikan dengan dimensi intellectual capital yang digunakan oleh Singh dan Zahn (2007) dalam Putuyana \& Budiarto (2018) dalam 6 kategori yang mencakup 81 item. Skala dikotomi tertimbang (unweughteddichotomousscale) digunakan dalam pemberian skor untuk setiap item pengungkapan diberi nilai 1, dan 0 apabila tidak diungkapkan.

$\mathbf{I C D I}=\frac{\sum_{\mathrm{ij}} \mathrm{D}_{\mathrm{item}}}{\sum_{\mathrm{ij}} \mathrm{AD}_{\mathrm{item}}}$

Keterangan :
ICDI : $\quad$ IC Disclosure index
$\boldsymbol{\Sigma}_{\mathrm{ij}} \mathrm{D}_{\text {item }}$ : $\quad$ Total skor item IC yang diungkapkan
$\boldsymbol{\Sigma}_{\mathrm{ij}} \mathrm{AD}_{\text {Item }} \quad$ : $\quad$ Total skor item ICyang seharusnya diungkapkan. 


\section{Nilai perusahaan}

Nilai perusahaan adalah persepsi investor terhadap tingkat keberhasilan perusahaan yang sering dikaitkan dengan harga saham. Rasio keuangan yang dapat digunakan untuk mengukur nilai pasar perusahaan adalah Tobin's Q. Rumus pengukuran menggunakan Tobin's Q yang digunakan dalam Putuyana \& Budiarto (2018) adalah sebagai berikut:

Tobin's Q =

$$
\frac{\mathrm{MVS}+\mathrm{D}}{\mathrm{TA}}
$$

Keterangan:

Tobin's Q: Nilai Perusahaan

MVS: Nilai pasar saham (market value of all outstanding shares) yang diperoleh dari hasil perkalian jumlah saham yang beredar dengan harga saham (out standing share $x$ stock price)

D: Nilai pasar hutang yang diperoleh dari hasil (kewajiban lancar - asset lancar + kewajiban jangka panjang)

TA: Total aset perusahaan.

\section{Good corporate governance}

Tata kelola perusahaan yang baik atau good corporate governance sangat penting untuk meningkatkan keberhasilan usaha dan akuntabiltas perusahaan guna mewujudkan nilai pemilik modal dalam jangka panjang dengan tetap memperhatikan kepentingan stakeholders perusahaan berlandaskan peraturan dan nilai etika. Proksi GCG dalam penelitian ini menggunakan salah satu proksi GCG yaitu dewan komisaris independen. Formula perhitungan proporsi dewan komisaris independen adalah: Jumlah dewan komisaris independen/jumlah total dewan komisaris) x 100\%.

\section{HASIL DAN PEMBAHASAN}

\section{Statistik deskriptif}

Tabel 1

Descriptive Statistics

\begin{tabular}{cccccc}
\hline & \multicolumn{1}{c}{} \\
\hline & $\mathrm{N}$ & Minimum & Maximum & Mean & Std. Deviation \\
ERMD & 198 & .31 & .77 & .5434 & .08259 \\
ICD & 198 & .20 & .68 & .4259 & .09605 \\
GCG(DKI) & 198 & .25 & .80 & .4153 & .10907 \\
NP & 198 & -.27 & 483.05 & 12.4648 & 55.18494 \\
Valid N (listwise) & 198 & & & & \\
\hline
\end{tabular}

Sumber: data diolah

Berdasarkan Tabel 1 dapat dilihat bahwa terdapat 198 sampel yang digunakan dalam penelitian ini. Pada pengungkapan Enterprise risk management (ERM) dari tabel tersebut dapat diketahui bahwa nilai minimalnya adalah sebesar 0,31 dan nilai maksimumnya adalah sebesar 0,77 . Rata-rata pengungkapan yang dilakukan adalah sebesar 0,5434 yang artinya tingkat kepatuhan pengungkapan pada perusahaan manufaktur sudah tergolong sedang. Nilai standar deviasi untuk ERM adalah sebesar 0,082 .

Pada pengungkapan Intellectual capital (IC) yang berdasarkan indikator pengungkapan dalam Pratiwi (2019) yang terdiri dari 81 item, nilai minimum yang didapatkan adalah sebesar 0,20 dan nilai maksimumnya adalah sebesar 0,68 . Rata-rata pengungkapan yang dilakukan adalah sebesar 
0,4259 yang artinya tingkat kepatuhan terhadap pengungkapan IC pada perusahaan manufaktur juga sudah tergolong sedang. Nilai standar deviasi pengungkapan IC sebesar 0,096.

Nilai perusahaan yang diproksikan dengan menggunakan Tobin's Q pada penelitian ini menunjukkan bahwa nilai minimum adalah sebesar -0,27 dan untuk nilai maksimum sebesar 483,054. Rata-rata nilai perusahaan untuk perusahaan manufaktur sebesar 12,464 yang artinya sudah cukup baik karena memiliki nilai rata-rata lebih besar dari 1 dengan standar deviasi sebesar 55,1849.

Good Corporate Governance (GCG) yang pada penelitian ini diproksikan dengan dewan komisaris independen menunjukkan nilai minimum sebesar 0,25 dan nilai maksimum sebesar 0,80 . Nilai minimum tersebut menunjukkan jumlah presentasepaling kecil dari perbandingan jumlah dewan komisaris independen dengan total jumlah dewan komisaris yang ada di perusahaan yang menjadi sampel dalam penelitian ini. Nilai rata-rata yang ditunjukkan adalah sebesar 0,41 dengan standar deviasi sebesar 0,1097.

\section{Uji Asumsi Klasik}

Uji Normalitas dilakukan dengan menggunakan Uji Kolmogorov-Smirnov dilihat dari nilai 2tailed significant dengan pengukuran tingkat sig sebesar 0,05 . Hasil pengujian diketahui bahwa nilai signifikansi sebesar 0,582 yang lebih besar dari 0,05, sehingga dapat dikatakan data telah berdistribusi normal. Uji Multikolinearitas dilakukan untuk menguji ada tidaknya korelasi antar variabel bebas pada model regresi. Dari hasil pengujian diketahui semua variabel memiliki nilai tolerance value $>0,10$ atau $\mathrm{VIF}<10$ yang artinya model regresi tidak terjadi multikolinearitas. Uji Heteroskedasitas dilakukan menggunakan Uji Glejser untuk mengetahui apakah model regresi memiliki gejala heteroskedasitas. Jika nilai sig $>$ alpha 0,05 , maka regresi tidak mengalami heteroskedastisitas. Dari hasil uji diketahui nilai signifikansi untuk semua variabel adalah sig $>0,05$ sehingga dapat dikatakan tidak ada gejala heteroskeasitas pada variabel penelitian. Uji Autokorelasi menggunakan pendekatan Durbin Watson (DW) untuk melihat data yang diuji menggandung autokorelasi atau tidak. Hasil uji diketahui nilai Durbin Watson (DW) adalah 1,971. Rumus uji autokorelasi $\mathrm{Du}<\mathrm{Dw}<(4-\mathrm{Du})$. $\mathrm{Du}=1,8193$ dan 4-DU $=2,1807$. Maka 1,8193 $<1,971<2,1807$ yang artinya model regresi ini tidak terdapat autokorelasi.

\section{Analisis Regresi Berganda Persamaan 1}

Uji Koefisien Determinasi (R2) dilakukan untuk mengukur sejauh mana variabel independen dapat menjelaskan variasi variabel dependen. Dapat dilihat pada Tabel 2

Tabel 2

Hasil uji determinasi (R2)

\begin{tabular}{ccccc}
\hline \multicolumn{5}{c}{ Model Summary } \\
\hline Model & $\mathrm{R}$ & R Square & Adjusted R Square & Std. Error of the \\
& & & & Estimate \\
1 & $.321^{\mathrm{a}}$ & .103 & .089 & .57913
\end{tabular}

Predictors: (Constant), Good Corporate Governance, Intellectual Capital Disclosure,

Enterprise Risk Management Disclosure

Sumber: data diolah

Berdasarkan Tabel 2 tersebut terlihat bahwa nilai Adjusted $R$ Square sebesar 0,089. Hal ini mengidentifikasikan bahwa variabel independen pengungkapan ERM, pengungkapan IC, dan variabel moderasi GCG mampu menjelaskan sebanyak 8,9\% nilai perusahaan dipengaruhioleh variabel tersebut sedangkan sisanya dipengaruhi oleh variabel lain di luar penelitian.

Uji F dilakukan untuk mengetahui apakah variabel independen berpengaruh secara simultan terhadap variabel dependen. Dari hasil uji yang disajikan pada Tabel 3 menunjukkan bahwa uji $\mathrm{F}$ adalah sebesar 7,436 dan nilai signifikansi $\mathrm{F}$ yakni $0,000<$ nilai alpha $=0,05$, sehingga terdapat pengaruh secara simultan variabel pengungkapan ERM, pengungkapan IC dan variabel moderasi GCGterhadap variabel nilai perusahan. 
Wacana Ekonomi (Jurnal Ekonomi Bisnis dan Akuntansi), 19 (2) 2020, 85

\begin{tabular}{|c|c|c|c|c|c|c|}
\hline \multicolumn{7}{|c|}{$\begin{array}{c}\text { Tabel } 3 \\
\text { Hasil Uji F }\end{array}$} \\
\hline \multicolumn{2}{|c|}{ Model } & $\begin{array}{l}\text { Sum of } \\
\text { Squares } \\
\end{array}$ & Df & Mean Square & $\mathbf{F}$ & Sig \\
\hline \multirow[t]{3}{*}{1} & Regression & 7.482 & 3 & 2.494 & 7.436 & $.000^{\mathrm{b}}$ \\
\hline & Residual & 65.067 & 194 & .335 & & \\
\hline & Total & 72.549 & 197 & & & \\
\hline \multicolumn{7}{|c|}{ a. Dependent Variable: Nilai Perusahaan } \\
\hline \multicolumn{7}{|c|}{ Predictors: (Constant), ERMD,ICD,GCG } \\
\hline \multicolumn{7}{|c|}{ Sumber: data diolah } \\
\hline
\end{tabular}

Uji t merupakan uji untuk mengetahui pengaruh secara parsial pada variabel independen terhadap variabel dependen. Jika nilai signifikan dibawah 0,05 maka menunjukkan ada pengaruh antara variabel independen terhadap dependen.

Tabel 4

Hasil uji t

\begin{tabular}{|c|c|c|c|c|c|}
\hline \multicolumn{6}{|c|}{ Coefficients $^{\mathrm{a}}$} \\
\hline \multirow[t]{3}{*}{ Model } & \multirow{2}{*}{\multicolumn{2}{|c|}{$\begin{array}{l}\text { Unstandardized Coeffi- } \\
\text { cients }\end{array}$}} & \multirow{3}{*}{$\begin{array}{c}\text { Standardized } \\
\text { Coefficients } \\
\text { Beta }\end{array}$} & \multirow[t]{3}{*}{$\mathrm{t}$} & \multirow[t]{3}{*}{ Sig. } \\
\hline & & & & & \\
\hline & B & Std. Error & & & \\
\hline 1 (Constant) & 1.669 & .228 & & 7.317 & .000 \\
\hline ERMD & .443 & .404 & .114 & 1.096 & .274 \\
\hline ICD & .553 & .278 & .206 & 1.990 & .048 \\
\hline GCG & .224 & .173 & .088 & 1.295 & .197 \\
\hline \multicolumn{6}{|c|}{ a. Dependent Variable: Nilai Perusahaan } \\
\hline Sumber: data diolah & & & & & \\
\hline
\end{tabular}

Berdasarkan Tabel 4 pengujian regresi linear, maka dapat diperoleh model persamaan regresi sebagai berikut:

\begin{tabular}{cccccc}
\hline Model & $\begin{array}{c}\text { Sum of } \\
\text { Squares }\end{array}$ & Df & Mean Square & F & Sig \\
\hline 1 Regression & 7.482 & 3 & 2.494 & 7.436 & $.000^{\mathrm{b}}$ \\
Residual & 65.067 & 194 & .335 & & \\
Total & 72.549 & 197 & & & \\
a. Dependent Variable: Nilai Perusahaan & & & & \\
Predictors: (Constant), ERMD,ICD,GCG & & & & \\
Sumber: data diolah
\end{tabular}

$\mathrm{Y}=1,669+0,443 \mathrm{ERMD}+0,553 \mathrm{ICD}+0,224 \mathrm{GCG}+\mathrm{e}$ 


\section{Moderated Regression Analysis (MRA)}

Untuk mengetahui pengaruh secara parsial pada variabel independen terhadap variabel dependen setelah adanya interaksi dengan variabel moderasi GCG dilakukan uji regresi moderasi. Berdasarkan pada tabel pengujian moderated regression analysis (MRA) pada Tabel 5 maka diperoleh persamaan regresi sebagai berikut:

$$
\mathrm{Y}=2,751+0,966 \mathrm{ERMD}+1,505 \mathrm{ICD}+1,450 \mathrm{GCG}+0,509 \mathrm{ERMD} * \mathrm{GCG}+
$$

\section{Tabel 5}

Hasil uji Moderated Regression Analysis(MRA)

\begin{tabular}{|c|c|c|c|c|c|}
\hline \multicolumn{6}{|l|}{ Coefficients $^{\mathrm{a}}$} \\
\hline \multirow{3}{*}{ Model } & \multirow{2}{*}{\multicolumn{2}{|c|}{$\begin{array}{l}\text { Unstandardized } \\
\text { Coefficients }\end{array}$}} & Standard- & $\mathrm{T}$ & Sig. \\
\hline & & & $\begin{array}{l}\text { ized Coeffi- } \\
\text { cients }\end{array}$ & & \\
\hline & $\mathrm{B}$ & $\begin{array}{l}\text { Std. Er- } \\
\text { ror }\end{array}$ & Beta & & \\
\hline 1 (Constant) & 2.751 & .426 & & 6.451 & .000 \\
\hline ERMD & .966 & .620 & .248 & 1.559 & .121 \\
\hline ICD & 1.505 & .438 & .561 & 3.437 & .001 \\
\hline GCG & 1.450 & .447 & .572 & 3.242 & .001 \\
\hline ERMD*GCG & .509 & .563 & .177 & .904 & .367 \\
\hline $\mathrm{ICD} * \mathrm{GCG}$ & 1.132 & .413 & .575 & 2.739 & .007 \\
\hline \multicolumn{6}{|c|}{ Dependent Variable: Nilai Perusahaan } \\
\hline \multicolumn{6}{|l|}{ Sumber: data diolah } \\
\hline $1,132 \mathrm{ICD} * \mathrm{GCG}+\mathrm{e}$ & & & & & \\
\hline
\end{tabular}

Tabel 6

Hasil Uji F

\begin{tabular}{cccccc}
\hline \multicolumn{1}{c}{ ANOVAa } & & & \\
\hline Model & Sum of Squares & Df & Mean & F & Sig. \\
& 10.639 & 5 & Square & & \\
1 Regression & 61.910 & 192 & .322 & & \\
Residual & 72.549 & 197 & & & \\
Total & & & & &
\end{tabular}

a. Dependent Variable: Nilai Perusahaan

Predictors: (Constant), ERMD,ICD,GCG,ERM*GCG,ICD*GCG

Sumber: data diolah

Berdasarkan Tabel 6 dapat dilihat bahwa output hasil pengujian uji F setelah adanya interaksi adalah sebesar 6,599 dan nilai signifikansi $F$ yakni $0,000<$ nilai alpha $=0,05$. Hal ini menunjukkan bahwa model persamaan regresi setelah adanya interaksi variabel independen dengan variabel moderasi sama-sama berpengaruh secara simultan terhadap variabel dependen. 
Tabel 7

Hasil uji Koefisien determinasi (R2)

\begin{tabular}{|c|c|c|c|c|}
\hline \multicolumn{5}{|c|}{ Model Summary } \\
\hline Mode & $\mathrm{R}$ & R Square & Adjusted R Square & $\begin{array}{c}\text { Std. Error of the Es- } \\
\text { timate }\end{array}$ \\
\hline 1 & $.383^{\mathrm{a}}$ & .147 & .124 & .56784 \\
\hline \multicolumn{5}{|c|}{ a. Predictors: (Constant), ERMD,ICD,GCG,ERMD*GCG,ICD*GCG } \\
\hline \multicolumn{5}{|c|}{ Sumber: data diolah } \\
\hline
\end{tabular}

Berdasarkan Tabel 7 terlihat bahwa nilai Adjsted $R$ Square sebesar 0,124. Hal ini menjelaskan bahwa variabel independen ERM disclosure, IC disclosure, variabel moderasi GCG dan hasil interaksi variabel independen ERM disclosure dan IC disclosure dengan variabel moderasi GCG yang diproksikan dengan DKI, mampu menjelaskan bahwa sebanyak 12,4\% nilai perusahaan dipengaruhi oleh variabel-variabel tersebut sisanya dipengaruhi oleh variabel lain diluar penelitian.

\section{Pembahasan Pengujian Hipotesis}

\section{H1: Pengungkapan enterprise risk management berpengaruh positif terhadap nilai perusahaan}

Berdasarkan hasil uji statistik t pada Tabel 4 variabel pengungkapan enterprise risk management (ERMD) dapat dilihat bahwa nilai signifikansi sebesar 0,274> alpha =0,05 dengan arah koefisien regresi sebesar 0,443. Nilai t hitung sebesar 1,096 dan t tabel sebesar 1,97227 yang artinya $t$ hitung $<\mathrm{t}$ tabel. Hal ini berarti variabel pengungkapan ERM tidak berpengaruh terhadap nilai perusahaan. Dengan demikian, maka dapat disimpulkan bahwa hipotesis pertama (H1) yang mengatakan bahwa pengungkapan ERM berpengaruh positif terhadap nilai perusahaan pada penelitian ini tidak didukung. Hasil ini menunjukkan bahwa pengungkapan ERM bukanlah variabel yang mempengaruhi nilai perusahaan. Dalam teori signal menyatakan bahwa informasi merupakan unsur penting bagi investor dalam pengambilan keputusan. ERM merupakan suatu pendekatan yang sangat penting untuk mengidentifikasi, menganalisa, dan memonitor risiko ataupun peluang di dalam maupun di luar lingkungan yang dihadapi perusahaan. Namun itu tidak cukup bagiinvestor untuk menggunakan informasi ERM sebagai pertimbangan dalam berinvestasi. Investor cenderung menggunakan faktor lain sebagai pertimbangan. Hasil penelitian ini sejalan dengan penelitian yang dilakukan oleh Rivandi (2018), Naomi (2017) dan Siregar (2019) yang menemukan bahwa pengungkapan ERM tidak berpengaruh terhadap nilai perusahaan. Investor tidak melihat informasi tentang manajemen resiko dalam mengambil keputusan untuk melakukan investasi. Hasil penelitian ini tidak sejalan dengan penelitian yang dilakukan oleh Devi dkk. (2017) dan Pratiwi (2019) yang mengatakan bahwa pengungkapan ERM berpengaruh positif terhadap nilai perusahaan.

\section{H2: Pengungkapan Intellectual Capital (IC) berpengaruh positif terhadap nilai perusahaan}

Berdasarkan hasil uji statistik t pada Tabel 4 variabel pengungkapan intellectual capital menunjukkan nilai signifikansi sebesar sebesar $0,048<$ alpha $=0.05$ dengan arah koefisien regresi sebesar 0,553 . Nilai $t$ hitung sebesar 1,990 dan $t$ tabel sebesar 1,97227 yang artinya $t$ hitung $>t$ tabel bahwa variabel pengungkapan IC berpengaruh positif terhadap nilai perusahaan. Dengan demikian, maka dapat disimpulkan bahwa hipotesis kedua (H2) yang menjelaskan bahwa pengungkapan IC berpengaruh positif terhadap nilai perusahaan diukung. Hasil ini sejalan dengan Teori Sinyal yang menunjukkan bahwa pengungkapm informasi terkait aset tak berwujud yang dimiliki perusahaan akan meningkatkan kepercayaan investor dan stakeholder terhadap perusahaan. Informasi yang didapat investor melalui intellectual capital disclosure memberikan gambaran kondisi perusahaan sehingga investor tertarik untuk melakukan investasi terhadap perusahaan tersebut. Investor yakin bahwa informasi terkait unsur-unsur intellectual capital seperti sumber daya manusia, struktur organisasi, dan hubungan dengan pelanggan merupakan aspek-aspek penting untuk memaksimalkan kinerja perusahaan. Sehingga investor mempertimbangkan untuk melakukan investasi yang pada akhirnya akan menaikkan nilai perusahaan. Hasil penelitian ini sejalan dengan penelitian yang dilakukan oleh Devi dkk. (2017), Rivandi (2018) dan Siregar (2019) yang menemukan bahwa 
pengungkapan IC berpengaruh positif dan signifikan terhadap nilai perusahaan. Hasil penelitian tidak sejalan dengan penelitian yang dilakukan oleh Pratiwi (2019) dan Putuyana \& Budiarto (2018) yang mengatakan bahwa pengungkapan IC tidak berpengaruh terhadap nilai perusahaan.

\section{H3: Good corporate governance (GCG) memperkuat pengaruh pengungkapan enterprise risk management terhadap nilai perusahaan}

Berdasarkan hasil uji statistik moderated regression analysis pada Tabel 5 dapat diketahui bahwa nilai uji t interaksi variabel ERMD*GCG sebesar $0,367>\alpha=0,05$ disertai dengan nilai koefisien sebesar 0,509. Nilai t-hitung sebesar 0,904 < dari t-tabel 1,97240. Hal ini menunjukkan bahwa variabel good corporate governance tidak mampu memoderasi pengungkapan enterprise risk management terhadap nilai perusahaan. Dengan demikian hipotesis ketiga (H3) dalam penelitian ini tidak didukung. Pengungkapan ERM dalam suatu perusahaan menggambarkan adanya tata kelola risiko perusahaan yang baik. Teori agensi menjelaskan bahwa keberadaan komisaris independen sebagai bagian dari tata kelola perusahaan yang baik penting agar tidak terjadi benturan kepentingan antara perusahaan dengan pemegang saham. Namun berdasarkan hasil analisis regresi pada uji interaksi antara ERM dan GCG yang diproksikan dengan dewan komisaris independen membuktikan bahwa GCG tidak mampu memoderasi pengaruh pengungkapan ERM terhadap nilai perusahaan. Pengawasan yang dilakukan oleh dewan komisaris independen terhadap tata kelola perusahaan yang baik dalam hal melakukan pengungkapan manajemen risiko belum mampu untuk membuat investor tertarik untuk menilai kinerja suatu perusahaan. Hal ini mengindikasikan bahwa investor tidak mempertimbangkan informasi tersebut dalam pengambilan keputusan.

\section{H4: Good Corporate governance (GCG) memperkuat pengaruh pengungkapan intellectual capital (IC) terhadap nilai perusahaan}

Berdasarkan uji statistik moderated regression analysis pada tabel 5 menunjukkan bahwa nilai uji t interaksi antara variabel ICD*GCG diperoleh nilai signifikansi sebesar $0,007>\alpha=0,05$ disertai nilai koefisien sebesar 1.132. Nilai t hitung sebesar 2,739> dari t tabel 1,97240. Hal ini menunjukkan bahwa good corporate governance corporate yang diproksikan dengan dewan komisaris independen mampu memoderasi pengaruh pengungkapan intellectual capital terhadap nilai perusahaan sehingga hipotesis keempat (H4) dalam penelitian ini didukung. Pengungkapan modal intelektual menunjukkan informasi perusahaan jangka panjang, sehingga investor bisa mempertimbangkan pengungkapan modal intelektual sebagai informasi yang penting. Suatu tata kelola yang baik ditunjukkan dengan transparansi informasi yang diungkapkan. Teori Agensi menyatakan bahwa dengan adanya struktur tata kelola perusahaan yang baik dapat mencegah terjadinya konflik keagenan dengan pengendalian dan pengawasan yang dilakukan. Penerapan GCG dapat ditunjukkan dengan peran komisaris independen dalam melakukan pengungkapan dan transparansi perusahaan tersebut sehingga memberikan dampak positif terhadap nilai perusahaan. Dengan demikian GCG merupakan variabel yang mampu memoderasi pengaruh intellectual capital terhadap nilai perusahaan. Hal ini bisa dibuktikandengan hasil penelitian yang menunjukkan nilai positif. Semakin baik pengawasan yang dilakukan oleh dewan komisaris independen dalam hal pengungkapan intellectual capital, maka nilai perusahaan juga semakin meningkat. Hasil penelitian sejalan dengan penelitian yang dilakukan oleh Verawaty dkk. (2017) yang menemukan bahwa GCG dapat memoderasi pengaruh intellectual capital terhadap nilai perusahaan. Namun hasil penelitian ini tidak sejalan dengan penelitian yang dilakukan oleh Suparsa dkk. (2017) yang membuktikan bahwa Good Corporate Governance tidak mampu memoderasi pengaruh intellectual capital disclosure pada nilai perusahaan.

\section{SIMPULAN}

Berdasarkan hasil uji dan analisis yang dilakukan dalam penelitian ini, dapat diambil kesimpulan sebagai berikut:

Pengungkapan Enterprise Risk Management tidak berpengaruh terhadap nilai perusahaan. Investor dalam mengambil keputusan tidak menggunakan informasi ERM sebagai pertimbangan dalam pengambilan keputusan untuk berinvestasi. Investor cenderung menggunakan faktor lain sebagai pertimbangan.

Pengungkapan Intellectual Capital berpengaruh positif signifikan terhadap nilai perusahaan. Hasil ini menunjukkan informasi terkait asset tak berwujud yang dimiliki perusahaan akan 
meningkatkan kepercayaan investor dan stakeholder terhadap perusahaan. Informasi yang didapat investor melalui pengungkapan intellectual capital memberikan gambaran kondisi perusahaan sehingga investor tertarik untuk melakukan investasi terhadap perusahaan tersebut (Rivandi, 2018).

Good Corporate Governance yang diproksikan dengan dewan komisaris independen tidak mampu memoderasi pengaruh pengungkapan ERM terhadap nilai perusahaan. Pengawasan terhadap pengungkapaninformasi risiko dalam tata kelola perusahaan yang baik yang dilakukan oleh dewankomisaris independen belum mampu untuk membuat investor tertarik untuk menilai kinerja suatu perusahaan.

Good Corporate Governance yang diproksikan dengan dewan komisaris independen dapat memperkuat pengaruh pengungkapan intellectual capital terhadap nilai perusahaan. Peran komisaris independen dalam melakukan pengungkapan sukarela seperti pengungkapan modal intelektual perusahaan mampu mempengaruhi investor untuk berinvestasi. Dengan demikian GCG merupakan variabel yang mampu memoderasi pengaruh intellectual capital terhadap nilai perusahaan.

\section{DAFTAR REFERENSI}

Aditya, O., \& Naomi, P. (2017). Penerapan Manajemen Risiko Perusahaan dan Nilai Perusahaan di Sektor Konstruksi dan Properti. Esensi: Jurnal Bisnis Dan Manajemen, 7(2). https://doi.org/10.15408/ ess.v7i2.4981

Agista, G. G., \& Mimba, N. P. S. H. (2017). Pengaruh Corporate Governance Structure Dan Konsentrasi Kepemilikan Pada Pengungkapan Enterprise Risk Management. E-Jurnal Akuntansi Universitas Udayana, 20(1), 438-466. Retrieved from https://ojs.unud.ac.id/index.php/Akuntansi/article/ view/28368

Ardianto, D., \& Rivandi, M. (2018). Pengaruh Enterprise Risk Management Disclosure, Intellectual Capital Disclosure dan Struktur Pengelolaan terhadap Nilai Perusahaan. Jurnal Profita, 11(2), 284. https:// doi.org/10.22441/profita.2018.v11.02.009

Cecasmi, J. A., \& Samin, S. (2019). Pengaruh Dewan Komisaris, Leverage, dan Struktur Kepemilikan Terhadap Pengungkapan Enterprise Risk Management (ERM). Equity, 20(2), 5. https:// doi.org/10.34209/equ.v20i2.627

Devi, S., Budiasih, I. G. N., \& Badera, I. D. N. (2017). Pengaruh Pengungkapan Enterprise Risk Management dan Pengungkapan Intellectual Capital Terhadap Nilai Perusahaan. Jurnal Akuntansi Dan Keuangan Indonesia, 14(1), 20-45. https://doi.org/10.21002/jaki.2017.02

Farhani, A., \& Andraeny, D. (2018). Pengaruh Karakteristik Dewan Komisaris Terhadap Tingkat Pengungkapan Wajib Setelah Konvergensi IFRS (Studi pada Perusahaan Manufaktur yang terdaftar di Bursa Efek Indonesia periode 2015-2016) (IAIN SURAKARTA). Retrieved from http://eprints.iainsurakarta.ac.id/2923/

Handayani, B. D. (2017). Mekanisme Corporate Governance, Enterprise Risk Management, dan Nilai Perusahaan Perbankan. Jurnal Keuangan Dan Perbankan, 21(1), 70-81. Retrieved from http:// jurnal.unmer.ac.id/index.php/jkdp/article/view/1228

Hapsari, A. A. (2018). Pengaruh Good Corporate Governance (GCG) dan Corporate Social Responsibility Terhadap Nilai Perusahaan. Jurnal Bakti Masyarakat Indonesia, 1(1). https://doi.org/http:// dx.doi.org/10.24912/jbmi.v1i1.1900

Hery. (2015). Manajemen Resiko Bisnis (Enterprise Risk Management) "Every Employee Is Risk Owner". Jakarta: PT Grasindo.

Khan, S. N., Ismail, E., \& Ali, E. (2018). The Moderating Effect Of Intellectual Capital On The Relationship Between Corporate Governance And Companies. Journal of Governance and Integrity (JGI), 2(1), 29 -55. Retrieved from https://jgi.ump.edu.my/index.php/en/volume-2-issue-1-december-2018/92-themoderating-effect-of-intellectual-capital-on-the-relationship-between-corporate-governance-andcompanies-performance-in-pakistan/file 
Mariani, D., \& Suryani, S. (2018). Pengaruh Enterprise Risk Management Disclosure, Intellectual Capital Disclosure dan Corporate Social Responsibility Disclosure Terhadap Nilai Perusahaan dengan Profitabilitas sebagai Variabel Pemoderasi (Studi Empiris Pada Perusahaan Sektor Industri Baran. Jurnal Akuntansi Dan Keuangan, 2(7), 119-138. Retrieved from https://journal.budiluhur.ac.id/ index.php/akeu/article/view/766

Muslih, M., \& Mulyaningtyas, C. T. (2019). Pengaruh Corporate Governance, Kompetisi dan Karakteristik Perusahaan Terhadap Pengungkapan Risiko Perusahaan. Jurnal ASET (Akuntansi Riset), 11(1), 179188. https://doi.org/https://doi.org/10.17509/jaset.v11i1.17303

Pamungkas, A. S., \& Maryati, S. (2017). Pengaruh Enterprise Risk Management Disclosure, Intellectual Capital Disclosure dan Debt To Aset Ratio Terhadap Nilai Perusahaan. Prosiding Seminar Nasional Darmajaya, 1(1), 412-428. Retrieved from https:/jurnal.darmajaya.ac.id/index.php/PSND/article/ view/869

Puspitasari, E., \& Ermayanti, D. (2019). Pengaruh Corporate Social Responsibility Terhadap Nilai Perusahaan Dengan Good Corporate Governance Sebagai Variabel Moderasi (Studi Empiris Perusahaan Perbankan BUMN Go Public yang Terdaftar di BEI Periode Tahun 2011-2018). SEMINAR NASIONAL EKONOMI DAN BISNIS, (1), 29-40. Retrieved from https:// ejournal.stiedewantara.ac.id/index.php/SNEB/article/view/409

Putuyana, A. A., \& Budiarto, D. S. (2018). Pengungkapan Enterprise Risk Management dan Intellectual Capital: Apakah Bermanfaat bagi Perusahaan Real Estate? Jurnal A kuntansi Dewantara, 2(2), 183 193. https://doi.org/http://dx.doi.org/10.26460/ad.v2i2.3076

Rivandi, M. (2018). Pengaruh Enterprise Risk Management Disclosure Dan Corporate Governance Terhadap Nilai Perusahaan. Jurnal Benefita, 3(2), 137. https://doi.org/10.22216/jbe.v3i2.3113

Sulistyaningsih, S., \& Gunawan, B. (2018). Analisis Faktor-Faktor yang Memengaruhi Risk Management Disclosure (Studi Empiris pada Perusahaan Manufaktur yang Terdaftar di Bursa Efek Indonesia Tahun 2012-2014). Riset A kuntansi Dan Keuangan Indonesia, 1(1), 1-11. https://doi.org/10.23917/ reaksi.v1i1.1973

Suparsa, I. M. J., Ramantha, I. W., \& Badera, I. D. N. (2017). Kemampuan Good Corporate Governance Dalam Memoderasi Pengaruh Intellectual Capital Disclosure dan Reputasi Auditor Pada Nilai Perusahaan. E-Jurnal Ekonomi Dan Bisnis Universitas Udayana, 6(2), 505-532. Retrieved from https:// ojs.unud.ac.id/index.php/EEB/article/view/24175

Suryanata, K. B., Hermanto, H., \& Pituringsih, E. (2019). Ukuran Perusahaan, Nilai Perusahaan, dan Pengungkapan CSR terhadap Manajemen Risiko dengan Good Corporate Governance sebagai Pemoderasi. E-Jurnal Akuntansi, 28(3), 2076. https://doi.org/10.24843/EJA.2019.v28.i03.p28

Tambunan, M. C. S., Saifi, M., \& Hidayat, R. R. (2017). Pengaruh Good Corporate Governance Terhadap Nilai Perusahaan (Studi pada Perusahaan Sub Sektor Food and Beverages yang Terdaftar di BEI Tahun 2012-2015). Jurnal Administrasi Bisnis, 53(1), 49-57. Retrieved from http:// administrasibisnis.studentjournal.ub.ac.id/index.php/jab/article/view/2181

Verawaty, V., Merina, C. I., \& Lastari, S. A. (2017). Pengaruh Intellectual Capital, Earnings Management, Tax Avoidance Terhadap Nilai Perusahaan dengan GCG sebagai Pemoderasi. Journal Management, Business, and Accounting, 16(2), 79-94. https://doi.org/https://doi.org/10.33557/mbia.v16i2.66 